\title{
GENDER-MARKED CONCEPTUAL METAPHOR WOMAN IS A BIRD \\ (USING EXAMPLES FROM BULGARIAN AND CROATIAN LANGUAGES)
}

\author{
Ana Vasung \\ Faculty of Humanities and Social Sciences \\ University in Zagreb
}

Key words: conceptual metaphor, animalistic metaphor, anthropomorphism, woman is a bird, Bulgarian language, Croatian language, gender stereotypes, gender linguistics

Summary: The subject of the paper is the gender marked conceptual metaphor WOMAN IS A BIRD in two closely related languages - Bulgarian and Croatian languages. The corpus of analyzed ornithonyms, which are metaphorically used for a female referent, was collected from general monolingual and phraseological dictionaries, as well as online and slang dictionaries. Some meanings were illustrated by examples from the online corpora hrWac and Bulgarian web 2012 through the use of the Sketch engine tool. Even though domestic and wild birds are evenly represented in the analyzed corpus, the domestic birds are semantically and metaphorically more productive. The contrastive analysis established that the majority of metaphors are based on anthropomorphism, and that pejorative terms, which serve to semantically derogate women, dominate over terms with positive connotations. We have found pejorative connotations and hints of sexism even in the case of terms of endearment, which are supposed to express a special intimacy and congeniality. Interlingual differences, in the sense of the existence of more specific meanings, are realized within the framework of age and sexual connotation. The interlingual and intralingual variations (Kövecses, 2005, 2015) are the result of the dependency of metaphorical meaning on context and participants in the communication process. 


\title{
RODNO OBILJEŽENA KONCEPTUALNA METAFORA ŽENA JE PTICA (NA PRIMJERIMA IZ HRVATSKOG I BUGARSKOG JEZIKA)
}

\begin{abstract}
Ana Vasung
Filozofski fakultet

Sveučilište u Zagrebu

Ključne riječi: konceptualna metafora, animalistička metafora, antropomorfizam, žena je ptica, bugarski jezik, hrvatski jezik, rodni stereotipi, rodna lingvistika.

Sažetak: Tema rada je rodno obilježena konceptualna metafora ŽENA JE PTICA u dvama bliskosrodnim jezicima - bugarskom i hrvatskom jeziku. Korpus analiziranih ornitonima, koji se u prenesenom značenju rabe za referenta ženskog spola, prikupljen je iz jednojezičnih općih i frazeoloških rječnika te online rječnika i rječnika žargona. Pojedina su značenja oprimjerena iz mrežnih korpusa hrWac i Bulgarian web 2012, pomoću alata Sketch engine. Iako su u analiziranom korpusu podjednako zastupljene domaće i divlje ptice, domaće su semantički i metaforički produktivnije. Kontrastivnom je analizom utvrđeno da je većina metafora utemeljena na antropomorfizmu te da pejorativnost u funkciji semantičke derogacije žena dominira nad pozitivno obilježenim značenjima. Čak i u slučaju odmilica, koje bi trebale izraziti osobit odnos bliskosti ili simpatičnosti, zabilježili smo pejorativnost $\mathrm{i}$ naznake seksizma. Međujezične razlike u smislu postojanja specifičnijih značenja realiziraju se u okviru kategorije dobi i seksualne konotacije. Međujezične i unutarjezične varijacije (Kövecses, 2005, 2015) rezultat su ovisnosti metaforičkog značenja o kontekstu i sudionicima u komunikaciji.
\end{abstract}




\section{Introduction to the gender marked conceptual metaphor}

There is no doubt about the existence of inherent difference between the social position of women and men, and such gender inequality is also reflected in language. In the article "Language and Woman's Place" from 1973, the founder of feminist linguistics, Robin Lakoff (2018), proposes that social gender inequality is reflected in language in two ways: 1) The manner in which language treats men and women; 2) The language used by women and men (male and female language). In this paper, we will focus on the first form of linguistic manifestation and explore certain forms of linguistic shaping of the cultural concept of FEMININITY. Gender, but not only gender, stereotypes are manifested in linguistic practice through metaphorical expressions with negative connotations. Dale Spender, a radical feminist, invokes a semantic rule according to which the formation of meaning is dependent on dividing the world between a positivemasculine and negative-feminine (2018: 82-83). According to this semantic rule, each symbol associated with women has to take on negative and oftentimes sexual connotations. Lakoff (2018) also claims that epithets and metaphors often have a broader frame of reference when referring to men, while those same metaphors and epithets will have a narrower scope, and assume sexual connotations, when applied to women. On the other hand, metaphorical expressions, primarily idioms, carry an inherently negative connotation, therefore it is questionable to what extent such a claim can be justified with the referent's gender (cf. Hrnjak, 2017).

In this paper, we start with the conceptual metaphor as the formation mechanism of the gender-marked lexemes and idioms. Even though numerous papers and projects were written in Croatia on the topic of conceptual metaphor theory (cf. Stanojević, 2014), there is a lack of papers which analyze only gender-marked metaphors (cf. Hrnjak, 2017 $)$.

The majority of research has been conducted in the English language:

\footnotetext{
${ }^{1}$ In the book Phraseology within the Gender Framework, A. Hrnjak (2017) starts with the FEMININITY and MASCULINITY concepts and analyzes the gender-marked idioms, but does not establish the conceptual metaphor as the theoretical framework of her paper.
} 
DESIRED WOMAN AS SMALL ANIMAL, WOMAN AS DESSERT (Hines, 1999; 2000)

WOMAN ARE OBJECTS/SUBSTANCES, WOMAN ARE FOOD, WOMAN ARE ANIMALS, WOMAN ARE FEMALE RELATIVES (Kövecses, 2002)

Furthermore, there are also numerous contrastive studies of animalistic conceptual metaphors (ANIMAL METAPHORS) referring to women:

English-Italian-French (Baider, Gesuato, 2003), English-Spanish (Fernández Fontecha, Jiménez Catalán, 2003) (López Rodríguez, 2009), Serbian-Romanian (Silaški, Kilyeni, 2014).

An interesting recent paper elaborates the WOMAN IS A CAR metaphor among speakers of Bosnian, Croatian, Montenegrin and Serbian languages (Bratić, Vuković Stamatović, 2017).

All of the listed papers abound in metaphors which serve the function of semantic derogation of women. Semantic derogation is a term which assumes both pejorative connotations and polarization (Fernández Fontecha, Jiménez Catalán, 2003: 772), and confirms the androcentric nature of language, i.e. its focus on men (cf. Lakoff, Turner 1989; Spender, 2018; Milić, 2013).

The animalistic metaphor is most productive as the mechanism of semantic derogation of women. Although the animalistic metaphor is universal and based on mapping from the animal domain into the human domain, and it is common to call people animals in all cultures, it also varies from culture to culture. Starting from the conceptual metaphor theory within the animalistic metaphor WOMAN IS A BIRD, in this paper we compare the metaphorical concepts of women in the Bulgarian and Croatian languages. The goal of this paper is to ascertain what bird names are used as positive or negative metaphors for women, and to discover conceptual (motivational) links between linguistic expressions and their meanings. 


\section{Animalistic metaphor}

Aristotle wrote that man was an animal endowed with the gift of speech $^{2}$, therefore we can assume that the quest for finding the animal in humans, but also human in animals, is as old as the world. The first evidence of anthropomorphism ${ }^{3}$ dates back to Paleolithic cave drawings depicting animals with human characteristics. Animals with human traits are the main protagonists of fables, which are deemed to be the "main reason" why animal stereotypes are implanted early in childhood (cf. Barčot, 2017; Bertoša, 1999; Visković, 2007). The tendency opposite to anthropomorphism is called zoomorphism, and refers to attributing animal characteristics to humans. In language, zoomorphism is observed in pejorative terms for humans (i.e. chick for women, horse for men, or pig for an obese person) and idioms motivated by the animalistic world. According to Barčot (2014: 482), sometimes it is hard to differentiate between anthropomorphism and zoomorphism, therefore zoomorphism is also considered as the opposite of anthropomorphism. Double metaphorization is specific for anthropomorphism; human characteristics are attributed to an animal only to be mapped to man (Vidović Bolt, 2007: 417).

From a cognitive perspective, this type of mapping from the animal to the human domain is framed with the conceptual metaphor PEOPLE ARE ANIMALS, within which we have a series of mappings. ${ }^{4}$ (Kövecses, 2002; Milić, 2013). Although it is an universal metaphor, which exists in almost all languages, the importance of cultural shouldn't be deemed less important, i.e. existence of cultural diversity - it is hard to imagine that in India, where a cow is considered a holy animal, that same animal would be used as a derogatory term for women. Additionally, all animals are not equally represented nor have negative connotations. In order to understand

\footnotetext{
2 Thus, it is clear, a man is a social animal, more than any bee or other herd animal. Like they say, nature does nothing in vain. And of all the animals, only humans have speech https://filozofskitekstovi.wordpress.com/2010/03/31/politika-zoon-politikon/

${ }_{3}^{3}$ Anthropomorphism is the attribution of human characteristics and behavior to non-human entities http://struna.ihij.hr/naziv/antropomorfizam/24682/

4 Kövecses also lists other submapping within the conceptual metaphor PEOPLE ARE ANIMALS: HUMAN BEING IS ANIMAL, HUMAN BEHAVIOR IS ANIMAL BEHAVIOR, OBJECTIONABLE HUMAN BEHAVIOR IS ANIMAL BEHAVIOR, OBJECTIONABLE PEOPLE ARE ANIMALS, DIFFICULT TO HANDLE PEOPLE ARE DOGS, SEXUALLY ATTRACTIVE WOMAN ARE KITTENS (2002: 125).
} 
animal hierarchy, it is crucial to first establish the hierarchy of all living beings. Such a hierarchical structure was depicted in the GREAT CHAIN METAPHOR, which was introduced by Lakoff and Turner (1989).

It is a "basic cultural model by which beings and their attributes are ranked on a vertical scale as being "higher" or "lower" with their corresponding attributes" (1989: 166).

- HUMANS: Higher-order attributes and behavior (e.g. thought, character)

- ANIMALS: Instinctual attributes and behavior

- PLANTS: Biological attributes and behavior

- COMPLEX OBJECTS: Structural attributes and functional behavior

- NATURAL PHYSICAL THINGS: Natural physical attributes and natural physical behavior.

Entities of every order possess all of traits of lower ranked entities, and act in accordance with those characteristics. This means that humans also possess instinctual attributes and behaviors, but animals do not have mental and character traits. Furthermore, authors state: "The basic assumption is that "higher-order" questions are answered in terms of "lower-order" descriptions: the human place in the world is viewed in terms of ants on a millstone, human slander in terms of the properties of charcoal, human character in terms of the behavior of cows and horses, and similar" (1989: 161-162).

Aside from the hierarchical organization of living beings, hierarchical organization also exists among animals which can be used to somewhat explain the larger representation of some animals over others, and the greater degree of negative connotation of some. R. Išpekova's (1994) associates the hierarchy of the animalistic world, based on the metaphorical concept of animals, with the mythological representation of the Tree of Life, which is based on the orientational metaphor GOOD IS UP, BAD IS DOWN 5 . In that type of hierarchy, animals assume their places in such a way that birds are at the top, and ungulates reside in the tree (horses, cows, sheep, deer, etc.), with reptiles and amphibians nestled in the roots (Išpekova,

${ }^{5}$ More about metaphor see Lakoff, Johnson (1989). 
1994: 40-41). Thus, animals at the top were given positive traits, while those at the bottom received negative traits. If we apply this conceptualization to, say, a bird and a snake, the bird, as an animal of the "higher-order", has more positive characteristics compared to the snake; as a "lower-order" animal. But there are also numerous deviations from this metaphor, in the world of birds there are certain entities that only have positive characteristics (i.e. nightingale, swallow), while others are given negative characteristics and symbolism (i.e. crow, raven, cuckoo ${ }^{6}$ ).

Furthermore, some animals are metaphorically more productive than others. The generally accepted viewpoint (cf. Thornton, 1988; Holandi, 2010; Vidović Bolt, 2007; Visković, 2009; Vitanova 2012) is that domestic animals are more metaphorically productive because they are "closer and more familiar to man, and it is easier to transfer own traits onto them" (Visković, 2007: 362), which leads to the conclusion that animals more familiar to man are more widely represented among zoonyms used to name and describe people. By applying the division of animals into classes, Thornton (1988: 434) ascertains that mammals are the largest group in the English language, and crabs are the smallest, while among mammals the dog is in the forefront, followed by the cat. Interesting data is presented by J. Rakušan (2000), on the basis of comparison of the English and Czech language, who discovered that in the Czech language farm animals are more prevalent relative to wild animals, with pets being placed in a separate group, which is numerically insignificantly weaker than farm animals; and she also makes a very interesting statement that wild birds are almost twice as prevalent in the English language compared to Czech, and approximately $5 \%$ more prevalent than farm animals. Regarding the prevalence of specific animals, she ascertained that dog was the most prevalent in both languages, followed by pig and then cat in Czech, with the other way around in English: cat, followed by pig. Even though there were no studies carried out in Bulgarian and Croatian languages that would provide us with equivalent

\footnotetext{
${ }^{6}$ According to Ladan (2006: 254) "many peoples and tribes considered the raven an ominous bird, which prophesies or heralds death or pestilence". But he also adds: "In Japan it is a symbol of familial love, because it truly loves its children", and "among some Pacific tribe, the raven is the creator and organizer of the world, which is definitely the highest position anyone has ever given". These examples confirm that the conceptualization of animals is culturally motivated and can vary from culture to culture, and even have the tendency to change over time.
} 
data, therefore a detailed overview of the animal names in a metaphorical sense and their distribution, the metaphorical productivity of zoonyms can also be determined from the data on their prevalence in animalistic idioms ${ }^{7}$. According to R. Holandi (2010), on the basis of contrastive analysis of English and Bulgarian animalistic idioms, domestic animals are represented in $50 \%$ of the total number of collected idioms in the Bulgarian language, while in English their number is smaller - they make up 30\% of the English language corpora. Wild animals are part of $22 \%$ idioms in the English language, and $15 \%$ in Bulgarian. Domestic and wild birds are placed in a special group, which is comprised of 17\% of idioms in English and 25\% of idioms in the Bulgarian language. In Croatian animalistic phraseology, based on the idioms collected in the Dictionary of Croatian Animalistic Idioms (2017) (hereinafter as DCAI), birds are a part of $18 \%$ of idioms, of which $45 \%$ are poultry, i.e. domesticated birds. These kinds of interlingual differences support the importance of taking into account the cultural differences of contrastive analysis, and it should be assumed that the greater the distance between cultures, the greater the difference of metaphorical productivity of animals. For instance, one study of animalistic metaphors in the Khezeli dialect (Aliakbari, Faraji, 2014) revealed that in that speech wild animals are more represented than domestic animals, and the conceptual metaphor HUMANS ARE UNDESIRED WILD ANIMALS was also established.

Animalistic metaphors are a reflection of human beliefs, attitudes, affinities and aversions towards animals, and they represent firm evidence of a strong connecting that exists between language and culture. Because stereotypes are deeply entrenched in culture, it is logical that animalistic metaphors will also serve gender ideology ${ }^{8}$. The animal world is also divided between "male" and "female", so even metaphorically, certain zoonyms are reserved exclusively for women or men. According to López,

7 According to the authors of the Dictionary of Croatian Animalistic Idioms, animalistic idioms may contain: zoonims, zoonimic derivative adjective, zoosomatic component and other components related to the animal world (habitat names, verbs whose meaning is connected to animals, onomatopoeic components and similar).

${ }^{8}$ But not just gender ideology. Many authors (Baider, Gesuato, 2005; López Rodríguez, 2009) believe that the animalistic metaphor is a conventional way of categorizing "the other" and, according to Turpin (2014: 8) „used to derogate and discriminate marginal groups such as homosexuals, immigrants and women, considered to be ,the other“““. 
the size of the animal is one of the factors, as well as whether they are wild or domesticated: „most animal metaphors used predominantly with men are usually based on size (big), strength and habitat (wilderness), whereas women are seen as domestic animals such as hen or parakeet" (2009: 83). Furthermore, women are perceived as pets to a greater extent because "they concentrate the sense of small size, youth, domesticity and entertainment" (Turpin, 2014: 13), which are stereotypically embedded female characteristics that are desirable from a male perspective. López (2009) states that women are also metaphorically identified with farmyard animals because of their edibility and servitude, but also because they are used for reproduction and are under human control. The motivation regarding wild animals is the complete opposite, they are perceived as dangerous and free, and they cannot be controlled, which López links to the conceptual metaphor SEX IS HUNTING, man is the hunter; the women his game.

Last but not least, the grammatical gender of the species name also needs to be taken into account because a different grammatical gender can condition a different conceptualization, followed by whether the male or female is perceived as the species' representative ${ }^{9}$, and how well known are pair nouns of the female and male of the animal species among speakers.

\section{Birds $^{10}$ in the animalistic metaphor}

The remainder of the paper will focus on ornithonyms which are metaphorically gender restricted, i.e. they are used (mainly) for female

\footnotetext{
${ }^{9}$ For instance, in the north of Croatia, the lizard (gušter) is perceived as the representative of the species, while in the south it is the female lizard (gušterica). Another example is how children acquire knowledge about animals through picture books, cartoons and stories, and when it comes to poultry, firstly they learn about the females; duck and goose, and only later do they learn about the males.

${ }^{10}$ In zoology, birds are defined as a class of bipedal, warmblooded vertebrae who lay eggs. There are between 9 and 10,000 known species of birds, and they are the most diverse class among land animals. For the purposes of this paper, we will not delve into the taxonomic orders of birds, the layman's division between wild and domestic birds will suffice, whereby the domestic birds are considered to be domestic poultry. First, we will analyze domestic birds, and then wild birds. Birds are listed based on their prevalence in the corpus.
} 
referents. As was mentioned in the previous chapter, birds are, when compared to domestic animals and mammals, an underrepresented species within animalistic metaphors. We will explore which birds are represented, and in what measure, in two closely related languages - Croatian and Bulgarian; whether they are wild or domestic birds, are there specific cultural differences, and what are the characteristics of women represented in the semantics of ornithonyms. Also, the goal is to establish whether anthropomorphism or zoomorphism is dominant in ornithological metaphors, and are they more closely tied to the behavior of birds (which can be instinctive behavior and a reflection of typically female characteristics) or their appearance.

Contrastive analysis was conducted on the basis of the corpus collected from general and idiom dictionaries of the two languages, online languages, slang dictionaries and scientific papers. Some meanings were illustrated by examples from the online corpora hrWac and Bulgarian web 2012 (BWEB) through the use of the Sketch engine tool.

\section{Hen, chicken (kokoš, kvočka / кокошка, квачка)}

In Bulgarian and Croatian languages, chicken is a derogatory term for a woman who is stupid and talks a lot. It is a typical example of anthropomorphism, i.e. the attribution of human traits (which in this case are considered to be typically female) to animals. STUPIDITY is primarily a human trait; lack of intelligence and ability to reason, and the description of certain manifestations of animal behavior as stupid or irrational is the achievement of an anthropomorphic world view and bringing animal traits to the human level. Many of the traits we ascribe to animals are actually their instinctive behavior, the nature of their instinct, which from a human perspective is deemed as stupidity, courage and similar (cf. Milić, 2013). Animals, as Johnson and Lakoff state in the aforementioned GREAT CHAIN METAPHOR, only have instinctual attributes and behavior, and everything within the domain of mental and character traits is uniquely human. According to Hrnjak (2017: 127), the conviction that birds are stupid animals derives from the comparison of the size of the human brain with the brain of a bird, therefore, the smaller (bird) brain is considered as a sign of 
intellectual limitation ${ }^{11}$. In addition to stupidity, women are also attributed with the trait of GARRULOUSNESS from the domain of the chicken. Garrulousness is conventionally attributed to women, even though it is questionable whether women speak more than men. Spender (2018: 100) states that "no study managed to prove that women speak more than men, and numerous studies have shown that men talk more than women". Female garrulity, according to Spender, is not measured in relation to men, but rather in relation to silence, i.e. it is evaluated whether they speak more than taciturn women, with taciturnity being a far more desirable female trait. Garrulousness is, as a stereotype connected to a woman's tongue, metaphorically mapped to chicken vocalization, i.e. clucking, whereby double stereotypization occurs - and the vocalization of chickens is perceived as excessive, superfluous, unnecessary, overly loud; not in relation to the rooster, but in relation to the silence.

In the Croatian language, we have also documented various derivatives of the noun kokoš (chicken), with specialized meanings. The usage of the diminutive term kokica to describe a young woman, as a term of endearment. This hypocoristic is primarily used by women when talking to their close friends, it doesn't have negative connotations and is not used for the semantic derogation of women ${ }^{12}$. The hypocoristic koka an also be used in female dialog, without negative implications, to describe an attractive woman $^{13}$. But there is another meaning that sexually objectifies women: Anić's Dictionary contains an idiom stara koka dobra juha (old hen, good soup) "an experienced woman provides the most pleasure to a man", while

\footnotetext{
11 According to an article published in Jutarnji List, professor Nathan Emery, from the Queen Mary University in London, writes in the book "Bird Brain: An Exploration of Avian Intelligence" that for a long time birds were unjustly considered stupid because they are lacking a cerebral cortex, but now it has been discovered that the other part of the bird's brain, pallium, has evolved to a point where it allows birds to execute tasks, such as the crafting of tools which are used as hooks. https://www.jutarnji.hr/life/znanost/ptice-su-najglupljastvorenja-na-zemlji-sveucilisni-profesor-rusi-sve-predrasude-da-samo-znate-sto-sve-mogunapraviti-vrane-ili-djetlici.../5227707/

${ }_{12}$ One recent study showed that women are equally inclined towards the semantic derogation of women: „that there is no significant difference between men and women in the degree of their use for semantic derogation of animal metaphors denoting women" (Silaški, 2013: 329).

${ }^{13}$ Nedavno sam bila $s$ dragim na jednoj svadbi, $i$ nisam ga nimalo tlacila, plesali smo $s$ razlicitim partnerima, on je pio i brbljao s deckima (i posve mi je svejedno jesu li zaista komentirali zgodne koke ili ne), jer i ja sam sjedila uz dvije simpa cure s kojima sam i ja komentirala frajere. hrWac
} 
the DCAI defines stara koka as a "sexually attractive older woman". Examples from the corpus ${ }^{14}$ confirm that stara koka can be used to describe an older attractive woman, but not exclusively, and sexual attraction can but doesn't have to be semantically prominent. Terms of endearment koka and kokica show a dynamic character, expansion of meaning is contextually conditioned and depends on the gender of the speaker, and with time they attain new meanings. In this case, the new meaning has sexual connotations, Sabljak (2013) states that in jargon koka means a "prostitute", but also a "male sexual organ". Dale Spender wrote about this phenomenon, she states that in the English language the word biddy (hen, chick; old hag) was introduced as a term of endearment, with the intention of portraying the women in a favorable light, but over time it was applied to young women who were sexually desirable. She also lists other terms of endearment that underwent systematic pejoration over time (2018: 85).

Unlike terms of endearments whose derogatory nature is hidden and contextually condition, the pejorative nature of the lexeme brooder (kvočka, квачка) is explicit. Anić's Dictionary defines brooder as a "mouthy, boring woman", while examples from the corpus show that it also refers to STUPIDITY ${ }^{15}$; the same is true for Bulgarian, even though it has not been documented in a dictionary. A brooder is a chicken that lays on eggs, unlike laying hens, which indicates the rising of its body temperature and the need to sit on eggs to keep them warm through clucking. This behavior is what motivated the coining of the idiom čuvati kao kvočka pilice, бди като квачка (fuss over them like a mother hen) which is used to disparage a woman (mother) who is overly worried, watchful and restrictive. Motivated by this image, the term hen is used on both languages with the same meaning. ${ }^{16}$

14 (1) Zanima me ovo: stavimo da postoji jedna koka, koju znate vec neki niz godina... uglavnom se susrecete u drustvu. Kada ste ju prvi put vidili, donja vilica je popustila u zglobu $i$ sline su vam pocele kapiti po podu. hrWac

(2) Vrlo bih rado posevio sestru, ona je ko grom, doktorica ni losa, no ipak je to koka u godinama, a izgleda da je ona glavna. hrWac

${ }^{15}$ I izlaze dečki iz brzog automobila, pa se deru kud hodaš kvočko glupa. Nemrem vjerovat. A njena frendica, prava kvočka glupa, smiruje situaciju i viče sori sori sori, nije bilo namjerno. hrWac

${ }_{16}$ (1) Че някой кара ли те да ги водии, да не са малки? - й отвърна - Вече са 3-ти клас, а ти - като квачка за всичко, сякаш са малки пиленцฺа! BWEВ 
Chick, a young chicken, is used metaphorically as a term of endearment in both languages, it is used in the interaction with a close female friend or a child, less often with a man (commonly in diminutive form: pilić, pilence, пиление).

Therefore, the zoonym pile (chick) is not used to derogate women, but chicken meat, i.e. piletina (chicken) is represented in the Croatian language (but also in other European languages) as a pejorative term used to describe women; and also men in more recent times. In examples from English slang, within the conceptual metaphor, Kövecses (2002) differentiates between submapping WOMAN ARE WHITE MEAT TO EAT, WOMEN ARE DARK MEAT TO EAT and WOMEN ARE APPETIZING (SWEET) FOOD. These metaphors are the result of sexism in language and the perception of women as sexual objects, Kövecses connects them to the metaphor SEX IS EATING, wherein the object of sex is food. Both metaphors are combined with the metaphor relating to sexual desire (LUST IS HUNGER), where the object of hunger is food, most commonly APPETIZING FOOD ${ }^{17}$ (Lakoff, 1987), and meat, as Kövecses claims: „As can be seen, the food is typically meat" (2009: 404). The reason for such metaphorization is observed in the generally accepted viewpoint that men prefer to eat meat more than women, but also in the hunter role which the man held in the past, and to which he is still inclined today. And here, too, the mapping is performed from the domain of sex, and at the root of the metaphor SEX IS HUNTING lies the quest for the ideal sexual partner, with men as the hunters and women as their game ${ }^{18}$. Because the goal of the hunt is the killing of the animal, in times past to eat meat, nowadays for fun, we believe that the conceptualization of women as meat is in the root of this metaphor as well $^{19}$. Furthermore, chicken, as a meat of a young animal, has a narrower

(2) Кунева не блестеше с особен интелект, но поне викаше само Йес, йес и не се зъбеше така на европейците. Тая квачка от Нова Загора е класи под Кунева! ВWEВ

${ }^{17}$ Kövecses gives an explanation why exactly sweet food is the submapping domain: „We do not eat appetizing food, especially sweet things, only to satisfy hunger, that is, to satisfy a need. We eat because we enjoy it, like it." (1986: 68)

${ }^{18}$ Kövecses connects this metaphor to the conceptualization of women as young female mammals, small furry animals, birds, but not with meat. (2009: 404)

${ }^{19}$ An article published on the feminist portal Libela states that a commercial by Gavrilović, a Croatian meat producer, equated women and sausages to meat, but we couldn't confirm it. https://www.libela.org/sa-stavom/4358-zena-objekt-zivotinja/ 
meaning within metaphoric mapping, it refers only to a young person ${ }^{20}$, but, as the newer examples of language use ${ }^{21}$, not exclusively a female. Therefore, meaning was expanded to include the male referent, also of young age, but this phenomenon confirms that language changes are keeping pace with social changes, and that gender equality is also reflected in language.

\section{Goose, duck (guska, patka / гъска, патка)}

The goose and duck are water birds, which in the real world, as well as in the metaphorical, have many similarities, so here we will consider them together. In both languages both birds are figuratively used to describe a stupid female person, and here, as with the chickens, we are dealing with anthropomorphism and the stereotypical conception of birds, especially poultry, as stupid animals. Croatian dictionaries also list augmentatives, such as gusketina, guščetina, while that phenomenon is not observed in Bulgarian.

In addition to stupidity, the goose is associated with infatuation in the Croatian language. We are of the opinion that this is a case where the concepts of STUPIDITY and INFATUATION have overlapped, because infatuation is considered be an irrational state in which a man (in this case a woman) cannot think rationally and her intellectual abilities are limited ${ }^{22}$. The perception of a goose as a stupid bird resulted in the attribution of infatuation.

\section{Turkey (tuka / мисирка)}

Tuka is a Croatian regional name for a turkey. It is very frequently used in the figurative sense and has surpassed its regional limitations. Turkey is also one of the members of poultry group which is used to disparagingly refer to a stupid female, equally used by male and female speakers, but we

\footnotetext{
${ }^{20}$ Anić provides the definition "young woman, without sexual experience", but we are of the opinion that the sexual meaning is not primary, but just one of the possible contextual achievements.

${ }^{21}$ One of the examples is an article in the "woman's" magazine Cosmopolitan titled Chicken vs. Old Fox, in which older and younger "guys" are compared and their experience is pointed out (but not only sexual). https://www.cosmopolitan.hr/clanci/medu-nama/piletina-vs-starilisac

$\frac{12}{22}$ This phenomenon is also at the root of the metaphor LOVE IS INSANITY (Lakoff, Johnson, 1980; Kövesces 1986).
} 
also note the non-pejorative usage as a term of endearment, when a woman is talking to another woman ${ }^{23}$.

The Bulgarian zoonym мисирка is also marked as regional and used in a pejorative manner to refer to stupid women ${ }^{24}$.

\section{Jackdaw, magpie (čavka, svraka / чавка, сврака)}

Jackdaw is one of the smallest birds from the crow family, it is recognizable by gray plumage over its stomach and short legs. In Bulgarian it is also called обикновена гарга (common crow) or just гарга (crow). Barčot lists examples of negative cultural perception of this bird: a trickster that adorns itself with borrowed plumes, a thief and chatterbox (191: 2017). On the basis of an associative survey which the author conducted amount native speakers of Croatian, it is concluded that the "anthropomorphic traits of the jackdaw as a chatty and annoying bird have embedded themselves into the consciousness of Croats through idioms" ${ }^{25}$. An analysis of the use of this zoonym in the hrWac corpus has shown that the noun is used predominantly in the plural form čavke (jackdaws) and contextually manifests in the concepts of PUGNACIOUSNESS, CONTENTIOUSNESS, CHATTINESS and VOCIFEROUSNESS, which is gender-restricted to a female referent. ${ }^{26}$ We find the same situation in the Bulgarian language, admittedly with much fewer examples of use $\mathrm{e}^{27}$, but the online jargon dictionary reveals that the zoonym is used for "a number of women who are talking". Unlike the Croatian language, in Bulgarian jackdaws are primarily

${ }^{23}$ Tuko jedna, da mi ovo više nikad nisi napravila. I love you sis. (taken from Bošnjak, 2014).

${ }^{24}$ Бъди мисирка и ще завладееш света или поне поп културата, както направиха Бритни Спиърс и Кристина Агилера. BWEB 2012.

${ }^{25}$ The author lists idioms brbljati kao čavka and kao čavke (chatter like a jackdaw; as jackdaws) implying "chatty and loud", the DCAI also records graktati kao čavke (caw like jackdaws) "yell, shout, speak loudly and in an annoying manner /referring to women" and svađati se (prepirati se) kao čavke (quarrel (argue) as jackdaws) "to quarrel (argue) loudly and inappropriately /referring to women".

${ }^{26}$ (1) Ma moj gornji komentar je ciljao prvenstveno na sve ove čavke koje su sad krenule galamiti. Malo je prešlo normalnu granicu i stvarno mi ide na živce. hrWac

(2) Vesele što se vidimo, odmah smo se zapričale... ko čavke Klepete-klepete Ah žene... hrWac ${ }^{27}$ We didn't register the use of zoonyms with abovementioned meaning in the network corpus, but we found it through the Google search engine:

(1) Тъпа статия, тъпо заглавие. Това, че някои чавки го правят не значи, че всички жени ще хукнат да се бръснат.

(2) Тези чавки като се съберат всеки път се карат, вместо да се веселят. 
associated with STUPIDTY, but without gender marking. This usage is motivated by the phrase чавка ми е изпила мозъка (акъла) (the jackdaw ate his brain) which is used to describe an extremely stupid person. But why are the abovementioned anthropomorphic traits attributed to the jackdaw? Unlike chickens, this is not a case of just conventional knowledge of the bird's vocalization ${ }^{28}$, which is metaphorically mapped into the aforementioned domains, rather this is a case of expanded cultural connotations which resulted from culturally based stereotypical beliefs originating from symbolism, beliefs, folk tradition and precedent texts (i.e. fables) in which the jackdaw is depicted with the aforementioned traits.

GARRULOUSNESS is attributed to another bird from the crow family the magpie. Unlike the jackdaw, the magpie is more recognizable due to its black and white body. Like a jackdaw, in Central European folklore it is believed to be a symbol of garrulousness, pugnacity and thievery. The survey conducted by Barčot confirmed that garrulousness is attributed to the magpie, and that the use is gender marked (2017: 215). Additionally, examples of use show that every magpie is also attributed with VOCIFEROUSNESS, PUGNACITY and COMPLAINING ${ }^{29}$. Anić also lists the meaning "a woman with thin legs", but we have not certified it in the corpus or recorded it in other dictionaries. The dictionary of Bulgarian language lists the meaning "a man with a sharp tongue" without gender marking, it doesn't fit in the abovementioned concept, but it does enter the semantic field of speech. However, Bulgarian speakers claim that the terms чавка, сврака and гарга (crow) can be used to describe an overly talkative woman.

\footnotetext{
${ }^{28}$ Ladan explains that birds from the crow family aren't songbirds, their call is far removed from normal birdsong, it is much closer to a raspy voice "caw-caw" and "kraa-kraa" (2004: 251).

${ }^{29}$ (1) takav dojam baš i ostavlja, lijena i ležerna osoba koja zna samo kričati kao svraka. što bi drugo lijeni ljudi mogli raditi nego si povisivati plaće? nije ni papire prevrnula na svome stole, a već si diže plaću, to može uraditi samo netko bez trunke osobnog morala $i$ odgovornosti. hrWac

(2) Ona je graknula kao svraka, da nema ona meni sto davat svoje ime, salje me u socijalno a socijalno potvrdjuje da sam u pravu.. hrWac
} 


\section{Cuckoo (kukavica/кукувица)}

The cuckoo is a bird from the Cuculidae family, in both languages the origin of the ornithonym is the recognizable call "cuckoo". It is most famous for laying its eggs in the nests of other birds, and it is also considered to be the herald of spring. In the Croatian language, but not in Bulgarian, a cuckoo is a "coward", therefore the anthropomorphic trait is also attributed to the bird. Great sorrow, misfortune, lamentation is expressed through crying out kuku (cuckoo), from which derivatives kukati (to gripe) and kukanje (to lament) arise, which are characteristic only to the Croatian language. We have not recorded a gender restricted use of the lexeme in Croatian. In the Bulgarian language it is extremely gender marked, but it is also used to describe a disagreeable older woman, and often with the attribute $\partial$ zpma ('old') ${ }^{30}$. This negative image is the result of conventional knowledge regarding the instinctual behavior of the female laying of eggs in the nests of other birds and ejecting their eggs. This behavior was metaphorically mapped to a female referent, according to Popova, in the Bulgarian language women who use help other people's help in raising their children are called cuckoos (2015: 37). Behind this "lack of care" for one's own progeny lies a very specific relationship between a male and female, which Ladan colorfully describes: "...they have no obligation towards their partners, so everyone is up for grabs" (2006: 273). The female is the one who wanders and meets a large number of available males, she is the one who is unfaithful, therefore the male has become a symbol of a man who was deceived and is called a cuckold in English, from the Latin cuculus (ibid). There is no such term in Croatian or Bulgarian languages, but that sort of female behavior was mapped to the concept of LONELINESS and кукувица also means a lonely person, but it is not gender marked.

\section{Owl, scops owl (sova, sivi ćuk / сова, кукумявка)}

Compared to other birds, the owl, as well as other birds from the owl family, has a rather unusual appearance, therefore it comes as no surprise that in the metaphorical language its physical traits are highlighted (wide and rounded heads, as well as a sharp and hooked beak, bright round eyes). In Croatian the zoonym is used to derogate women: Anić states that it is

${ }^{30}$ (1) Но пък тази дърта кукувица отдавна трябваше да слезе от сиената. ВWEB

(2) Само ограничен човек може да повярва на глупостите на тази дърта кукувица. Явно мислят собствените си хора за много прости. ВWEВ 
used to describe a "woman with bulbous eyes and beaked nose". Sabljak (2001) states that the term sova is used as a slang to describe a prostitute, but we couldn't verify this in the network corpus. In Bulgarian сова has no meaning which would relate to a woman, the dictionary states that the ornithonym сова is used in a figurative sense to describe a person who stays up until late at night. This usage has also been certified in the Croatian language (Bošnjak, 2014).

The use of the кукумявка (scops owl) ornithonym is specific for the Bulgarian language. It is used metaphorically to describe an ugly, disagreeable woman. In the Croatian language, the ornithonym sivi ćuk is not used in this sense, it is not gender marked, we assume it is due to the masculine grammatical gender, and the dictionary records its meaning as a "person of low intelligence, a stupid man".

The negative connotations surrounding these birds are surely motivated by the symbolism of an ominous bird, which announces impending doom through its hooting.

However, examples of use in the network corpora did not confirm the use pursuant with abovementioned meaning, and it is hard to make a conclusion regarding the metaphoric potential of ornithonyms in the modern language.

\section{Stork (roda / щъркел)}

The stork is a well-known migratory bird, a herald of spring, and most widespread belief is that they bring babies. In Croatian folk etymology, roda (stork) is connected to the verb roditi (to give birth), but the root of legged, long-necked and long-beaked" (Ladan, 2006: 274), the zoomorphic mapping is achieved in the domain of its physical appearance, so a longlegged girl ${ }^{31}$ is called a roda in the Croatian language, but it's also used to describe gait, but without gender restrictions. ${ }^{32}$ In the Bulgarian language, the stork is called щъркел, which is a Germanism, and it has no

\footnotetext{
${ }^{31}$ Dok sam bila mladja, mama mi je znala " savjetovati ": nemoj nositi visoke pete, izgledas previsoko; pa nemoj minicu, izgledas $k^{\prime}$ o roda; pa $i$ u dugoj suknji sam predugacka. hrWac ${ }_{32}$ Prvo uronite desnu nogu pod vodu pa hodajte kao roda između koraka podižite nogu potpuno iz vode kako biste stvorili efekt toplo-hladno. hrWac
} 
connotations regarding women, probably due to the influence of the (masculine) grammatical gender ${ }^{33}$.

\section{Pigeon, turtle dove (golubica, grlica / гълъбица, гургулица)}

Turtle doves and pigeons are members of the Columbiformes order, and because they are similar in almost every aspect, including symbolism, we will look at them together. Positive connotations are attributed to pigeons, in antiquity they were dedicated to goddesses of love, they are a holy bird and symbol of the Holy Ghost in Christianity. In many cultures, they are seen as a symbol of love, and the cooing of pigeons is interpreted as an expression of love; when they touch beaks, it seems like they're kissing. In recent times, they have been multiplying uncontrollably in the cities and have been burdened with the unflattering sobriquet of "Rats with Wings" (Ladan, 2006: 256). This is one of the rare birds that has established itself in the language as a term of endearment, used for talking to women and expressing tender feelings, with the difference that in Bulgarian гълъбииа and гургулии з $^{34}$ are used, and golubica in Croatian ${ }^{35}$.

\section{Conclusion}

In this paper we have researched the metaphorical meaning of 12 ornithonyms: chicken, goose, duck, turkey, jackdaw, magpie, cuckoo, owl, scops owl, stork, pigeon and turtle dove. The representation in both languages is largely similar, but there are some differences. In the Bulgarian language, кукувица (cисkоo) is extremely gender and age restricted, while that is not the case in Croatian. In the Croatian language, the ornithonym

\footnotetext{
${ }^{33}$ Even though this is not the subject of this paper, because the bird has no gender markings in a metaphorical sense, it is interesting to note that the stork has an extremely positive connotation in the Bulgarian folklore and culture, it is associated with spring and the Baba Marta national holiday, which is celebrated on the $1^{\text {st }}$ of March.

34 (1)Цялото ми същество ще засияе от щастие като видя прекрасните му очи, като чуя прекрасния му глас, който ще каже: гълъбице моя, покажи ми лището си, дай ми да чуя гласа ти, защото гласът ти е сладък, а лицето ти приятно. BWEВ

(2) Но не мисли, че ще ти го покажа, преди да ми се отдадеш изияло, гургулице моя ненагледна. Не спирам да мисля за теб (...) BWEB

${ }^{35}$ Zar mjesec dana te nismo vidjeli, zar mjesec dana te nismo dotakli, zar već toliko milujemo tvoj grob, pričamo sa tobom, čuješ li nas golubice naša, čuješ li jecanje naše. hrWac
} 
roda (stork) is used for a female referent, which is lacking in Bulgarian, probably due to the masculine grammatical gender of the equivalent lexeme щъркел. The situation is reversed in regards to the lexeme кукумявка (scops owl), which is gender marked in the Bulgarian language, while in Croatian (sivi ćuk) is not due to the masculine grammatical gender. The term golubica/гълъбица (pigeon) carries positive connotations in both languages, while гургулица (turtle dove) has positive connotations only in Bulgarian $^{36}$. The term kokoš (chicken) has a greater metaphorical productivity in the Croatian language, where we note the terms of endearment kokica and koka which have dynamic meaning and can be gender restricted and, depending on the context, also have sexual connotations. The gender and age restricted use of the lexeme piletina (chicken) is specific for Croatian, which can be used to allude to the lack of sexual experience. The conclusion may be drawn that there are more metaphorical expressions with sexual connotations in the Croatian language in comparison to Bulgarian.

The relation between the prevalence of wild and domestic birds is almost equal, but poultry covers a larger range of meanings. Therefore, domestic birds are more conventionalized and productive as a source domain for metaphors. They are linked to the concept of STUPIDITY (chicken, duck, goose, turkey) and GARRULOUSNESS (chicken, hen), which are stereotypically deemed female traits, and the metaphorization is exclusively based on anthropomorphism. We also discovered an interlingual asymmetry regarding the concept of INFATUATION, which is attributed to a goose only in the Croatian language.

Jackdaw and magpie are extremely metaphorically productive among wild birds, they are attributed the concepts of PUGNACIOUSNESS, GARRULOUSNESS, CONTENTIOUSNESS and VOCIFEROUSNESS, and examples of use show that they are mostly used in the plural form. We have ascertained that the pejorative use regarding these birds is not the result of just anthropomorphic mapping into the abovementioned domains based on the knowledge of bird behavior, but also cultural connotations.

\footnotetext{
${ }^{36}$ The fact that in the Croatian language the term dove doesn't have only positive associations tied to it was probably influenced by the idiom usrati se kao grlica (crap one's pants like a dove).
} 
The stork, owl and little owl are the only example of birds which are used in the domain of physical appearance, but again with a negative connotation, even in regards to the stork's long legs.

And lastly, the dove, which stands out as a bird with distinctly positive connotations, in both languages it is used as a term of endearment and for expressing tender feelings.

In conclusion, the metaphorical world of birds is characterized by anthropomorphism, androcentrism, and gender markedness. Pejorative terms which serve to semantically derogate women dominate over terms with positive connotations. We have found pejorative connotations and hints of sexism even in the case of terms of endearment, which are supposed to express a special intimacy and congeniality.

Comparison and analysis have shown the existence of more specific meanings within the category of age and sexual connotations. The nuances of meaning confirm the interlingual and intralingual variations which Kövecses $(2005,2015)^{37}$ pointed out, and they are the result of the dependency of metaphorical meaning on context and participants in the communication process. Thus, the universal aspect of metaphors (in this case regarding the metaphor WOMAN IS A BIRD) is reconciled with its variations that we found in the contrastive analysis of the two closely related languages..

\section{References}

Aliakbari, Mohammad, Faraji, Elham. (2014). Conceptualization of Man's Behavioral and Physical Characteristics as Animal Metaphors in the Spoken Discourse of Khezel People. Linguistik Online, 59 (2). Available at: https://doi.org/10.13092/lo.59.1141 (accessed April 23, 2020).

Anić, Vladimir. (2006). Veliki rječnik hrvatskoga jezika. Zagreb: Znanje.

Baider, Fabienne H., Gesuato, Sara. (2003). Mesculinist Metaphors, Feminist research. Metaphorik.de 05/2003. 6-35.

Barčot, Branka. (2017). Lingvokulturologija i zoonimska frazeologija. Zagreb: Hrvatska sveučilišna naklada.

Barčot, Branka. (2014). Antropomorfizam i zoomorfizam u hrvatskim, ruskim i njemačkim zoonimskim frazemima. Philological Studies, 2 (2014). 481-496.

${ }^{37}$ More available from J. Čizmar (2015) 
Bertoša, Mislava. (1999). Stereotipi o životinjama. In Badurina Lada, Ivanetić Nada, Pritchard Boris, Stolac Diana (Eds). Teorija i mogućnosti primjene pragmalingvistike. Rijeka/ Zagreb: Hrvatsko društvo za primijenjenu lingvistiku. 63-76.

Bošnjak, Aleksandra. (2014). Prenesena značenja hrvatskih imenica za životinje, diplomski rad. Zagreb: Faculty of Humanities and Social Sciences.

Bratić, Vesna, Vuković Stamatović, Milica. (2017). Commodification of women through conceptual metaphors: the metaphor woman as a car in the Western Balkans. Gender and Language, vol. 11.1 2017. 51-76.

Čizmar, Jelena. (2015). Uloga konceptualne metafore ČOVJEK JE BILJKA u sagledavanju razlika i sličnosti među kulturama hrvatskog i anglosaksonskog govornog područja, doktorski rad. Osijek: Josip Juraj Strossmayer University of Osijek, Faculty of Humanities and Social Sciences.

Fernández Fontecha, Almudena, Jiménez Catalán, Rosa Maria (2003). Semantic derogation in animal metaphor: a contrastive-cognitive analysis of two male/female examples in English and Spanish. Journal of Pragmatics 35 (2003). 771-797.

Hines, Caitlin. (1999). Foxy chicks and Playboy bunnies: A case study in metaphorical lexicalization. In Masako, K. Hiraga, Sinha, Chris, Wilcox, Sherman (Eds.). Cultural, Typological and Psychological Perspectives on Cognitive Linguistics. Amsterdam: Benjamins. 9-23.

Hines, Caitlin. (2000). Rebaking the Pie: The 'WOMAN AS DESSERT' Metaphor. In Bucholtz, Mary, Liang, Anita, Sutton, Laurel (Eds.). Reinventing Identities: The Gendered Self in Discourse. New York and Oxford: Oxford University Press. 145-162.

Holandi, Rajna. (2010). Зоонимната фразеология в английския и българския език. [Zoonimnata frazeologiya $\mathrm{v}$ angliskiya $\mathrm{i}$ bulgarskiya ezik]. Благоевград: Университетско издателство Неофит Рилски.

Hrnjak, Anita. (2017). Frazeologija u rodnom okviru. Zagreb: Knjigra.

Išpekova, Rosica F. (1994). Конвенционалните концептуални метафори и идеализираните когнитивни модели за животни [Konvencionalnite konceptualni metafori i idealiziranite kognitivni modeli za zhivotni.] Сыпоставително езикознание, XIX 1994, № 6. 38-44.

Kilyeni, Annamaria, Silaški, Nadežda. (2014). Beauty and the beast from a cognitive linguistic perspective: animal metaphors for women in Serbian and Romanian. Gender Studies, December 2014. 163-178.

Kövecses, Zoltan. (1986). Metaphors of Anger, Pride and Love. Amsterdam/Philadelphia: John Benjamins publishing company.

Kövecses, Zoltán. (2002). Metaphor. A Practical Introduction. Oxford: Oxford University Press. 
Kövecses, Zoltán. (2005). Metaphor in Culture: Universality and Variation. Cambridge: Cambridge University Press.

Kövecsez, Zoltán. (2009). Language and Ideology: The Case of Woman and Man in Slang. In Granić, Jagoda (Ed.) Jezična politika i jezična stvarnost. Zagreb: Hrvatsko društvo za primijenjenu lingvistiku - HDPL. 401-415.

Kövecses, Zoltán. (2015). Where Metaphors Come From: Reconsidering Context in Metaphor. Oxford/New York: Oxford University Press.

Ladan, Tomislav. (2004). Etymologicon. Tumač raznovrsnih pojmova. Zagreb: Masmedia.

Lakoff, George. (1987). Woman, Fire, and Dangerous Things. Chicago/London: The University of Chicago Press.

Lakoff, George, Johnson, Mark. (1980). Metaphors We Live By. Chicago: University of Chicago Press.

Lakoff, George, Turner, Mark. (1989) More than Cool Reason. A Field Guide to Poetic Metaphor. Chicago: The University of Chicago Press.

Lakoff, Robin T. (2018). Jezik i ženino mjesto. In Pišković, Tatjana (Ed.). Rodni jezici, Zbornik radova o jeziku, rodu i spolu. Zagreb: Zagrebačka slavistička škola. FF press. 37-73.

López Rodríguez, Irene. (2009). Of Women, Bitches, Chickens and Vixens: Animal Metaphors for Women in English and Spanish. Cultura, lenguaje y representación / culture, language and representation, vol VII, 2009. 77-100.

Milić, Goran. (2013). Pristup zoosemiji unutar teorije konceptualne metafore i metonimije. Jezikoslovlje 14/01/2013. 197-213.

Pišković, Tatjana. (2012). Hrvatski gramatički rod kao kulturem. FLUMINENSIA, 24 (2012), no. 2. 61-70.

Popova, Katažina. (2015). Птиците в българската и полската фразеология [Pticite v bulgarskata i polskata frazeologiya]. Научни трудове на Русенския университет, 2015, том 54, серия 6.3. 34-39.

Rakušan, Jaromira. (2000). Language constructs of animals and men in two cultures: Czech vs. English similes with animals in comparatum. Multilingua, 19-3, 265-279.

Sabljak, Tomislav. (2001). Rječnik hrvatskog žargona. Zagreb: V.B.Z.

Silaški, Nadežda. (2013). Animal metaphors and semantic derogation - do woman think differently from men? Gender Studies 12/2013. 319-332.

Spender, Dale (2018): Vjerovati ili ne vjerovati... istraživanjima jezika i spola. In Pišković, Tatjana (Ed.). Rodni jezici, Zbornik radova o jeziku, rodu i spolu. Zagreb: Zagrebačka slavistička škola. FF press. 73-115.

Stanojević, Mateusz-Milan. (2014). Metafore koje istražujemo: Suvremeni uvidi u konceptualnu metaforu. Zagreb: Srednja Europa.

Thornton, Freda J. (1988). A classification of the semantic field good and evil in the vocabulary of English. PhD thesis. University of Glasgow. 
Turpin, Esmeralda. (2014). A critical study of the WOMEN ARE ANIMALS conceptual metaphor, conference paper. Available at: https://www.researchgate.net/publication/267151007_A_CRITICAL_STUD Y_OF_THE_WOMEN_ARE_ANIMALS_CONCEPTUAL_METAPHOR (accessed April 23, 2020).

Vidović Bolt, Ivana. (2007). Metaforika zoonima u hrvatskoj frazeologiji. In Marjanić, Suzana, Zaradija Kiš, Antonija (Eds.). Kulturni bestijarij. Zagreb: Institut za etnologiju i folkloristiku - Hrvatska sveučilišna naklada. 403-423.

Vidović Bolt, Ivana et al. (2017). Rječnik hrvatskih animalističkih frazema. Zagreb: Školska knjiga.

Visković, Nikola. (2009). Kulturna zoologija: Što je životinja čovjeku i što je čovjek životinji. Zagreb: Naklada Jesenski i Turk.

Vitanova, Mariana (2012). Човек и свят: Лингвокултурологични проучвания. [Chovek i svyat: Lingvokulturologichni prouchvania]. София: Бул-Корени.

Online dictionaries:

https://ibl.bas.bg/rbe/

https://www.bgjargon.com/

https://www.zargonaut.com/

Online corpora:

https://www.sketchengine.eu/

(hrWac, BWEB 2012) 